\title{
Toksisitas Paraquat terhadap Chlorella sp. dalam Media Air Laut
}

\section{(Toxicity of Paraquat to Chlorella sp.in Sea Water)}

\author{
Sanjayadi $^{1^{*}}$, Sri Noegrohati ${ }^{2}$ \\ ${ }^{1}$ Program Studi Farmasi, Fakultas Kedokteran, niversitas Katolik Indonesia Atma Jaya,Jakarta \\ ${ }^{2}$ Fakultas Farmasi, Universitas Gadjah Mada, Yogyakarta, Indonesia
}

Article Info:

Received: 01 September 2017

in revised form: 18 September 2017

Accepted: 28 September 2017

Available Online: 01Oktober 2017

\section{Keywords:}

Paraquat,

Toxicity,

Chlorella,

$\mathrm{EC}_{50}$

Corresponding Author:
Sanjayadi
Prodi Farmasi
Fakultas Kedokteran
Universitas Katolik Indonesia
Atma Jaya
Jakarta
Indonesia
Phone : +62216693168 ext.183
Email: sanjayadi@atmajya.ac.id

\begin{abstract}
Paraquat (1-1'-dimethyl-4-4'-bipyridinium dichloride) is a non-selective herbicide, direct contact with wide spectrum, and widely used to control weed growth. Paraquat if distributed in aquatic environments, will affect the population of phytoplankton and interfere with the productivity of the aquatic environment. This study aims to determine the toxicity of paraquat to Chlorella sp., an important algae in food chain systems in aquatic environments, since the effects of herbicides on algae can affect trophic levels above them. 2.0 mililiter of paraquat concentrations of $2226.0 \mathrm{mg} / \mathrm{L}$; $1187.2 \mathrm{mg} / \mathrm{L} ; 593.6 \mathrm{mg} / \mathrm{L} ; 296.8 \mathrm{mg} / \mathrm{L} ; 148.4 \mathrm{mg} / \mathrm{L} ; 74.2 \mathrm{mg} / \mathrm{L} ; 37.1 \mathrm{mg} / \mathrm{L}$ and $18.6 \mathrm{mg} / \mathrm{L}$, were added to $250.0 \mathrm{~mL}$ of Chlorella $s p$. culture with a density of $150 \times 104$ cells $/ \mathrm{mL}$ in the sea water medium. The algae cell density in the medium is determined at intervals of $0,24,30,36,42,48,54$, 60, 66, and 72 using Neubauer Improved Haemocytometer under a microscope at 400 times magnification. The results of this study indicate that paraquat toxicity inhibition of population growth rate of Chlorella $s p$. Barriers to growth rates increase with the increasing of paraquat concentrations. At very high concentrations $(>471.11 \mu \mathrm{g} / \mathrm{L})$, the increased paraquat concentration practically did not result in an increase in the rate of growth of the Chlorella sp.Toxicity of paraquat population on Chlorella $s p$. quantitatively expressed with an $\mathrm{EC}_{50}$ of $125.8 \mu \mathrm{g} / \mathrm{L}$.
\end{abstract}

Copyright $(\mathrm{C}) 2017$ JFG-UNTAD

This open access article is distributed under a Creative Commons Attribution (CC-BY-NC-SA) 4.0 International license.

How to cite (APA 6th Style):

Sanjayadi., Noegrohati S., (2017). Toksisitas Paraquat terhadap Chlorella sp. dalam Media Air Laut. Jurnal Farmasi Galenika (Galenika Journal of Pharmacy), 3(2), 138-142. doi:10.22487/j24428744.2017.v3.i2.8756 


\begin{abstract}
ABSTRAK
Paraquat (1-1'-dimetil-4-4'-bipiridinium diklorida) merupakan herbisida non-selektif, kontak langsung dengan spektrum lebar, dan banyak digunakan untuk mengendalikan pertumbuhan gulma. Paraquat apabila terdistribusi dalam lingkungan perairan, akan mempengaruhi populasi fitoplankton serta mengganggu produktivitas lingkungan perairan tersebut. Penelitian ini bertujuan untuk mengetahui toksisitas paraquat terhadap Chlorella sp., suatu alga yang penting dalam sistem rantai makanan dalam lingkungan perairan, karena efek herbisida terhadap alga dapat mempengaruhi level trofik diatasnya. Sebanyak 2,0 mL paraquat dengan konsentrasi 2226,0 mg/L; 1187,2 mg/L; 593,6 $\mathrm{mg} / \mathrm{L} ; 296,8 \mathrm{mg} / \mathrm{L} ; 148,4 \mathrm{mg} / \mathrm{L} 74,2 \mathrm{mg} / \mathrm{L} ; 37,1 \mathrm{mg} / \mathrm{L}$ dan 18,6 mg/L, ditambahkan ke dalam 250,0 $\mathrm{mL}$ kultur Chlorella sp. dengan kepadatan $150 \times 10^{4} \mathrm{sel} / \mathrm{mL}$ dalam media air laut. Kepadatan sel alga dalam media tersebut ditentukan pada selang waktu jam 0, 24, 30, 36, 42, 48, 54, 60, 66, dan 72, menggunakan Haemocytometer Neubauer Improved di bawah mikroskop dengan perbesaran 400 kali. Hasil penelitian ini menunjukkan bahwa toksisitas paraquat berupa penghambatan laju pertumbuhan populasi Chlorella sp. Hambatan laju pertumbuhan meningkat dengan peningkatan konsentrasi paraquat. Pada konsentrasi yang sangat tinggi (> 471,11 $\mu \mathrm{g} / \mathrm{L})$, peningkatan konsenrasi paraquat praktis tidak mengakibatkan peningkatan hambatan laju pertumbuhan populasi Chlorella $s p$. Toksisitas paraquat terhadap Chlorella $s p$. secara kuantitatif dinyatakan dengan harga $\mathrm{EC}_{50}$, yaitu sebesar $125,8 \mu \mathrm{g} / \mathrm{L}$.
\end{abstract}

Kata Kunci : Paraquat, Toksisitas, Chlorella sp, $\mathrm{EC}_{50}$

\section{PENDAHULUAN}

Herbisida merupakan salah satu hasil dari revolusi kimia yang secara umum digunakan untuk mengendalikan gulma. Pada penggunaan herbisida, hanya sebagian kecil herbisida yang diaplikasikan benar-benar mencapai gulma target, dan sebagian besar sisanya terlepas ke lingkungan dan menyebabkan potensi efek yang mematikan pada spesies non target lainnya yang mempunyai peranan penting di lingkungan, misalnya alga (Pimentel 1995, Leboulanger et al. 2009; Prado at al., 2009). Alga merupakan bagian yang penting dari rantai makanan di lingkungan perairan, pengaruh herbisida pada alga dapat mempengaruhi tingkat trofik yang lebih tinggi dalam ekosisten air (Rioboo et al., 2007).

Paraquat (1-1' dimetil 4-4' bipiridinium diklorida) merupakan herbisida nonselektif, kontak langsung dengan spektrum lebar, dan banyak digunkan untuk mengendalikan pertumbuhan gulma berdaun lebar (Fuerst and Vaughn, 1990). Paraquat mengganggu proses fotosintesis dengan mengambil elektron pada tahap fotosistem I (PSI) yang seharusnya digunakan untuk mereduksi NADP menjadi NADPH. Akibatnya, paraquat tersebut menjadi bentuk radikal monokation tereduksi yang dapat bereaksi dengan oksigen menghasilkan anion superoksida, yang selanjutnya menyebabkan terbentuknya hidrogen peroksida dan radikal hidroksil (Eullaffroy dan Vernet, 2003). Radikalradikal ini menyebabkan perubahan ultrastruktur sel, yang meliputi degradasi protein, kerusakan DNA, peroksidasi lipid, dan selanjutnya kematian sel. Pada saat yang bersamaan, terkurasnya NADPH mengganggu proses biologis (Suntres, 2002). Toksisitas paraquat secara luas dapat digunakan sebagai model kerusakan yang diakibatkan oleh oksidasi (Jamers dan De Coen, 2010). Paraquat saat ini dilarang digunakan di sebagian negara, tetapi masih digunakan di beberapa negara.

Chlorella merupakan mikroalga hijau yang secara umum dapat ditemukan di lingkungan air tawar dan laut. Contoh Chlorella yang hidup di air laut antara lain Chlorella minutissima, Chlorella vulgaris, Chlorella pyrenoidosadan Chlorella virginica (Isnansetyo dan Kurniastuty, 1995).

Penelitian ini bertujuan untuk mengetahui toksisitas paraquat terhadap Chlorella sp. sebagai organisme tingkat trofik terendah dalam rantai makanan dalam lingkungan perairan.

\section{METODE PENELITIAN}

Alat

Timbangan digital (Scaltec), hot plate stirrer (IKA-Werk), autoklaf (Sakura), Haemocytometer Neubauer Improved, mikroskop (Kyowa - Tokyo), 
aerator, sumber cahaya ( lampu TL 50 watt), $\mathrm{pH}-$ meter (Mettler-Toledo), dan pengatur suhu udara.

\section{Bahan}

Paraquat diperoleh dari Zeneca. Chlorella sp. diperoleh dari Balai Budidaya Air Payau Kartini, Jepara. Kecuali dinyatakan lain bahan-bahan kimia yang digunakan adalah buatan Merck dengan mutu analisis: magnesium sullfat-heptahidrat, natrium nitrat, ammonium nitrat, dikalium hidrogen fosfattrihidrat, kalsium klorida-dihidrat, natrium karbonatdekahidrat, besi(III) sitrat, asam sitrat-monohidrat, asam borat, mangan klorida-tetrahidrat, seng klorida, tembaga sulfat pentahidrat, ammonium molibdattetrahidrat, asam klorida, natrium hidroksida. Akuades dan akua demineralisata buatan Laboratorium Kimia Analit, FMIPA, UGM.

\section{Metode}

1. Penyiapan Media Air Laut Buatan

A. Pembuatan trace element

Bahan bahan seperti yang tercantum pada Table 1. ditimbang dan dilarutkan dalam akuademineralisata sampai volume 1,0 L.

Tabel 1. Komposisi larutan trace element

\begin{tabular}{cll}
\hline No. & \multicolumn{1}{c}{ Senyawa } & $\begin{array}{c}\text { Berat } \\
(\mathrm{g})\end{array}$ \\
\hline 1. & asam borat, & 2,90 \\
2. & mangan klorida-tetrahidrat & 1,81 \\
3. & seng klorida, & 0,11 \\
4. & tembaga sulfat pentahidrat & 0,08 \\
5. & ammonium molibdat-tetrahidrat & 0,018 \\
\hline
\end{tabular}

B. Pembuatan air laut buatan

Pembuatan air laut buatan, dibuat dengan komposisi yang dapat dilihat pada tabel 2 .

Tabel 2. Komposisi senyawa makro media air laut

\begin{tabular}{cll}
\hline No. & \multicolumn{1}{c}{ Senyawa } & $\begin{array}{c}\text { Berat } \\
(\mathrm{g})\end{array}$ \\
\hline 1. & magnesium sullfat-heptahidrat & 0,075 \\
2. & natrium nitrat & 0,5 \\
3. & ammonium nitrat & 0,33 \\
4. & dikalium hidrogen fosfat-trihidrat & 0,052 \\
5. & kalsium klorida-dihidrat & 0,035 \\
6. & natrium karbonat-dekahidrat & 0,054 \\
7. & besi(III) sitrat & 0,006 \\
8. & asam sitrat-monohidrat & 0,006 \\
\hline
\end{tabular}

Bahan-bahan seperti yang tercantum pada Tabel 2. ditimbang dan dilarutkan dalam sebagian akuademineralisata. Kecuali magnesium sullfatheptahidrat dilarutkan terlebih dahulu dengan menggunakan akuademineralisata panas dan besi(III) sitrat digerus sebelum dilarutkan dalam akuademineralisata. Ke dalam campuran tersebut ditambahkan 1,0 $\mathrm{mL}$ larutan trace element dan ditambahkan akuademineralisata sampai 1,0 mL dan $\mathrm{pH}$ larutan diatur pada $7 \pm 0,3$ dengan menggunakan $\mathrm{HCl} 0,1 \mathrm{~N}$ dan $\mathrm{NaOH} 0,1 \mathrm{~N}$. Air laut buatan yang telah siap dimasukkan ke dalam Erlenmeyer dan disterilkan dengan menggunakan autoklaf.

\section{Uji toksisitas paraquat terhadap populasi \\ Chlorella sp.(OECD, 1981)}

Dibuat seri pengenceran 2226,0 mg/L; 1187,2 $\mathrm{mg} / \mathrm{L} ; 593,6 \mathrm{mg} / \mathrm{L} ; 296,8 \mathrm{mg} / \mathrm{L} ; 148,4 \mathrm{mg} / \mathrm{L} \quad 74,2$ $\mathrm{mg} / \mathrm{L} ; 37,1 \mathrm{mg} / \mathrm{L}$ dan $18,6 \mathrm{mg} / \mathrm{L}$ dari stok paraquat dengan konsentrasi $371,0 \mathrm{mg} / \mathrm{L}$. Dibuat kultur alga dengan kepadatan $150 \times 10^{4} \mathrm{sel} / \mathrm{mL}$. Dua ratus lima puluh koma nol mililiter alga dimasukkan ke dalam Erlenmeyer $500 \mathrm{~mL}$ yang kering dan steril ditambah 2,0 $\mathrm{mL}$ larutan seri pengenceran. Kultur alga diinkubasi dalam keadaan steril pada suhu $20^{\circ} \pm 2^{\circ} \mathrm{C}$ dengan penyinaran lampu TL 3 x 40 watt dan diberi aliran udara dengan menggunakan aerator. Kultur kontrol dilakukan dengan cara mengganti larutan paraquat dengan air laut buatan. Kepadatan alga dicacah pada waktu jam ke $0,24,30,36,42,48,54$, 60, 66, dan 72 .

Pencacahan alga dilakukan dengan cara: 0,5 $\mathrm{mL}$ kultur alga diambil dari kultur alga yang sedang diinkubasi pada waktu jam yang telah ditentukan. Sebagian kultur alga diteteskan pada Haemocytometer Neubauer Improved dan dicacah di bawah mikroskop dengan perbesaran 400 kali.

\section{HASIL DAN PEMBAHASAN}

Uji toksisitas populasi alga merupakan uji multi generasi. Uji multi generasi merupakan uji yang tidak hanya menguji organisme induk, tetapi juga organisme turunannya. Toksisitas paraquat terhadap populasi Chlorella sp. terlihat sebagai kemampuan menurunkan laju pertumbuhan populasi, semakin besar paraquat yang dipaparkan semakin besar penurunan laju pertumbuhan populai Chlorela sp. (Tabel 3). Laju pertumbuhan populasi alga (LPA) merupakan harga kemiringan dari kurva pertumbuhan pada fase eksponensial berlangsung. 
Table 3. Laju pertumbuhan populasi alga (LPA) pada setiap paparan konsentrasi paraquat

\begin{tabular}{lccc}
\hline No. & $\begin{array}{c}\text { Konsentrasi } \\
\text { paparan } \\
\text { paraquat } \\
(\mu \mathrm{g} / \mathrm{L})\end{array}$ & Pertumbuhan Chlorella $s p$. \\
& LPA $\pm \mathrm{SD}$ & $\% \mathrm{CV}$ \\
\hline 1. & kontrol & $0,0505 \pm 0,00230$ & 4,56 \\
2. & 15,84 & $0,0475 \pm 0,00193$ & 4,07 \\
3. & 29,68 & $0,0398 \pm 0,00096$ & 2,42 \\
4. & 58,89 & $0,0318 \pm 0,00091$ & 2,86 \\
5. & 117,78 & $0,0225 \pm 0,00032$ & 1,43 \\
6. & 235,58 & $0,0193 \pm 0,00005$ & 0,30 \\
7. & 471,11 & $0,0143 \pm 0,00051$ & 3,58 \\
8. & 942,22 & $0,0168 \pm 0,00044$ & 2,59 \\
9. & 1766,67 & $0,0124 \pm 0,00025$ & 2,02 \\
\hline
\end{tabular}

Semakin tinggi paparan konsentrasi paraquat menyebabkan semakin tingginya penghambatan laju pertumbuhan alga sampai batas tertentu sehingga kenaikan konsentrasi paraquat tidak dapat lagi meningkatkan kemampuan penghambatan LPA seperti yang terlihat pada Gambar 1. Hambatan laju pertumbuhan alga (HLPA) dihitung dengan rumus:

$$
H L P A=\left(1-\frac{R_{n}}{R_{0}}\right) \times 100 \%
$$

Keterangan:

$\mathrm{R}_{\mathrm{n}}$ : LPA pada kultur yang dipengaruhi masingmasing konsentrasi paraquat

$\mathrm{R}_{0}$ : LPA pada kultur yang tidak dipengaruhi oleh paraquat (kontrol)

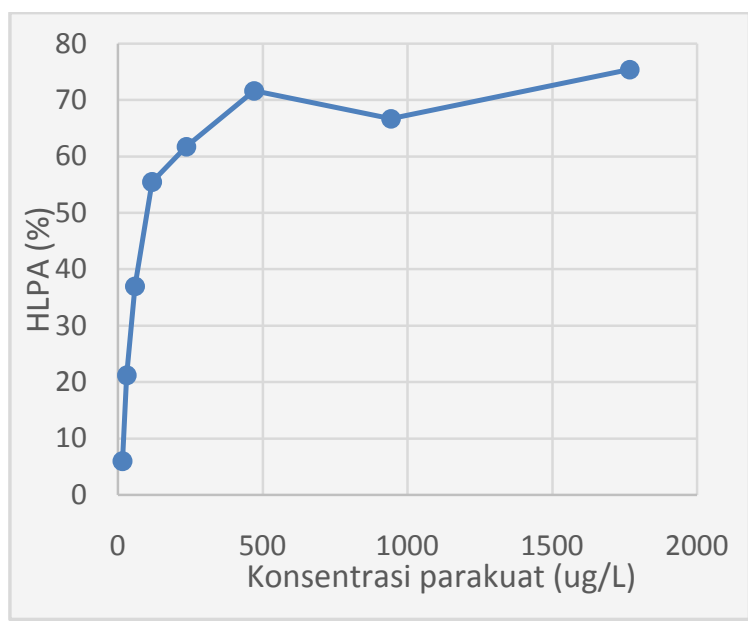

Gambar 1. Hambatan paraquat terhadap laju pertumbuhan populasi Chlorella $s p$.
Kuantitasi potensi toksisitas paraquat terhadap populasi alga dapat dinyatakan dengan harga $\mathrm{EC}_{50}$. $\mathrm{EC}_{50}$ adalah konsentrasi paraquat yang dapat menghambat LPA sebesar $50 \%$ bila dibandingkan dengan kontrol. Harga ini ditentukan dari kurva hubungan log konsentrasi paparan paraquat terhadap HLPA pada saat kenaikan konsentrasi paraquat menaikkan kemampuan penghambatan pertumbuhan populasi alga. Penelitian yang dilakukan memberikan data seperti pada Tabel 4 sebagai berikut:

Tabel 4. Penetapan $\mathrm{EC}_{50}$ paraquat terhadap LPA Chlorella sp.

\begin{tabular}{cccc}
\hline No. & $\begin{array}{c}\text { Konsentrasi } \\
\text { paparan } \\
\text { paraquat }(\mu \mathrm{g} / \mathrm{L})\end{array}$ & LPA & $\begin{array}{c}\text { HLPA } \\
(\%)\end{array}$ \\
\hline 1. & Control & 0,0505 & 0,00 \\
2. & 15,84 & 0,0475 & 5,94 \\
3. & 29,68 & 0,0398 & 21,19 \\
4. & 58,89 & 0,0318 & 37,03 \\
5. & 117,78 & 0,0225 & 55,45 \\
6. & 235,58 & 0,0193 & 61,78 \\
7. & 471,11 & 0,0143 & 71,68 \\
\hline
\end{tabular}

Regresi linier log konsentrasi paraquat vs HLPA diperoleh nilai $\mathrm{a}=45,159 ; \mathrm{b}=-44,817 ; \mathrm{r}_{2}=$ 0,9754 . Sehingga persamaan garis linier :

$$
\mathrm{y}=45,159 \mathrm{x}-44,817
$$

dimana, nilai $\mathrm{y}=50$, maka nilai $\mathrm{x}=2,0997$. Dengan demikian nilai $\mathrm{EC}_{50}=\operatorname{antilog} \mathrm{x}=125,8 \mu \mathrm{g} / \mathrm{L}$

Toksisitas paraquat terhadap populasi Chlorella sp. berupa penghambatan laju pertumbuhan populasi dengan nilai $\mathrm{EC}_{50} 125,8 \mu \mathrm{g} / \mathrm{L}$. Data ini menunjukkan bahwa paraquat sangat toksik terhadap Chlorella sp. yang merupakan alga hijau yang mampu melakukan fotosintesis. Dengan menurunnya kecepatan pertumbuhan alga ini, maka dikhawatirkan akan mempengaruhi biota tingkat trofik diatasnya.

Toksisitas paraquat terhadap populasi Chlorella sp. berupa penghambatan laju pertumbuhan populasi dengan nilai $\mathrm{EC}_{50} 125.8 \mu \mathrm{g} / \mathrm{L}$. Data ini menunjukkan bahwa paraquat sangat toksik terhadap Chlorella sp. dan sesuai dengan yang dilaporkan oleh Leboulanger et al (2009) yang menyatakan bahwa paraquat toksik terhadap fitoplankton. Chlorella sp. merupakan alga hijau yang mampu melakukan fotosintesis dan merupakan produsen dalam suatu ekosistem (Carr \& Neary, 2008). Oleh karena itu dengan menurunnya kecepatan pertumbuhan alga, maka dikhawatirkan akan mempengaruhi biota tingkat trofik diatasnya 
dan mengganggu kualitas ekosistem. Selain itu kemungkinan alga jenis lain juga terpengaruh oleh paraquat. Oleh karena itu maka perlu dilakukan penelitian lebih lanjut mengenai pengaruh paraquat terhadap alga lain yang menghasilkan energy mereka bukan dari fotosintesis

\section{KESIMPULAN}

Dari hasil penelitian, dapat disimpulkan bahwa Paraquat mampu menghambat laju pertumbuhan populasi Chlorella sp. dengan nilai $\mathrm{EC}_{50}$ sebesar $125,8 \mu \mathrm{g} / \mathrm{L}$

\section{DAFTAR PUSTAKA}

Carr,G.M.,Neary, J.P. (2008). Water Quality for Ecosystem and Human Health, 2nd Ed. Ontario: United Nation Environment Programme Publishing.

Eullaffroy P, Vernet G. (2003). The F684/F735 chlorophyll fluorescenceratio: a potential tool for rapid detection and determinationof herbicide phytotoxicity in algae. Water Res, 37, 1983-1990.

Fuerst EP, Vaughn KC. (1990). Mechanisms of paraquat resistance.Weed Technol, 4, 150156.

Isnansetyo, A., \& Kurniastuty. (1995). Teknik Kultur Phytoplankton dan Zooplankton. Yogyakarta: Penerbit Kanisius.

Jamers, A., De Coen, W. (2010). Effect assessment of the herbicideparaquat on a green alga using differential gene expression andbiochemical biomarkers. Environ Toxicol Chem, 29, 893-901.

Pimentel, D. (1995). Amounts of pesticides reaching target pests:environmental impacts and ethics. J Agric Environ Ethics, 8, 17-29.

OECD (1981).Test No. 201: Alga Growth Inhibition Test,OECD Guidelines for Testing of Chemical, Section 2: Effect of Biology System. Paris:OECD Publishing.
Prado, R., Rioboo, C., Herrero, C., Cid, A. (2009). The herbicide paraquatinduces alterations in the elemental and biochemical compositionof non-target microalgal species. Chemosphere, 76, 1440-1444.

Leboulanger, C., Bouvy, M., Pagano, M., Dufour, R., Got, P., Cecchi, P. (2009) Responses of planktonic microorganisms from tropicalreservoirs to paraquat and deltamethrin exposure. Arch Environ Contam Toxicol, 56, 39-51.

Rioboo,Ci., Prado, R., Herrero, C., Cid, A. (2007). Population growth studyof the rotifer Brachionus sp. fed with triazine-exposed microalgae. Aquat Toxicol, 83, 247-253.

Suntres, Z.E. (2002). Role of antioxidants in paraquat toxicity.Toxicology, 180, 65-77. 